\title{
Profil Kemampuan Komunikasi Geometris Siswa Kelas 8 di Era Pandemi Covid 19 Ditinjau dari Tipe Kepribadian Florence Littauer
}

Author:
Nanang Hadi Hariyanto ${ }^{1}$
Sunardi ${ }^{2}$
Erfan Yudianto $^{3}$
Nariyati $^{4}$
Affiliation:
1,2,3 University of Jember, East
Java, Indonesia
${ }^{4}$ SMP Negeri 1 Cluring
Banyuwangi, East Java,
Indonesia
Corresponding author:
Nanang Hadi Hariyanto,
nananghadi.galaxyv@ gmail.com
Dates:
Received: $27 / 2 / 2021$
Accepted: $11 / 3 / 2021$
Published: $16 / 3 / 2021$

\begin{abstract}
Abstrak. Profil kemampuan komunikasi geometri merupakan gambaran keterampilan komunikasi yang dapat membantu seseorang mengekspresikan dan memahami konsep-konsep geometri melalui suatu gambar. Tujuan penelitian ini adalah mendeskripsikan profil keterampilan komunikasi geometrik siswa kelas 8 selama pandemi covid 19 ditinjau dari tipe kepribadian florence littauer. Jenis penelitian ini adalah penelitian deskriptif dengan pendekatan kualitatif. Hasil penelitian ini menunjukkan bahwa siswa sanguinis pertama memiliki kemampuan komunikasi yang baik, siswa sanguinis kedua memiliki kemampuan komunikasi yang cukup baik. Mahasiswa tipe kolerik pertama memiliki kemampuan komunikasi yang baik, sedangkan mahasiswa tipe kolerik kedua memiliki kemampuan komunikasi yang buruk. Siswa tipe melankolis pertama memiliki kemampuan komunikasi yang kurang baik, sedangkan siswa tipe melankolis kedua memiliki kemampuan komunikasi yang cukup baik. Siswa tipe phlegmatik pertama memiliki kemampuan komunikasi yang sangat baik, sedangkan siswa kedua memiliki kemampuan komunikasi yang kurang baik.
\end{abstract}

Kata kunci: komunikasi, geometri, kepribadian

\begin{abstract}
The geometric communication ability profile is a description of communication skillsthat can help someone express and understand geometric concepts through an image. The purpose of study was to describe the geometric communication skills profile of $8^{\text {th }}$ graders during the covid 19 pandemic in terms of the personality type of florence littauer. this type of research is a descriptive study with a qualitative approach. The results of this study indicate that the first sanguinis student has goodcommunication skills, the second sanguinis student has quite good communication skills. The first choleric type students have good communication skills, while the second choleric students have poor communication skills. The first melancholic typestudent has poor communication skills, while the second melancholic student has fairly good communication skills. The firs phlegmatic tipe student has very good communication skills, while the second student has quite poor communication skills.
\end{abstract}

Keywords: Communication, geometry, personality

\section{J0M}

This work is licensed under a Creative Commons Attribution-ShareAlike 4.0 International License.

Read online:

https://jurnal.unej.ac.id/index.php/JOMEAL/index

or scan barcode beside.

How to cite this article:

Hariyanto, N., Sunardi, S., Yudianto, E., \& Nariyati, N. (2021). Profil Kemampuan Komunikasi Geometris Siswa Kelas 8 di Era Pandemi Covid 19 Ditinjau dari Tipe Kepribadian Florence Littauer. Journal of Mathematics Education and Learning, 1(1), 73-82. Retrieved from https://jurnal.unej.ac.id/index.php/JOMEAL/article/view/24377 


\section{Pendahuluan}

Pendidikan merupakan bimbingan yang diberikan oleh seorang pendidik kepada seorang murid yang biasa dilaksanakan di dalam kelas. Pada era pandemi covid 19 saat ini, pembelajaran yang ada di sekolahan akan dilaksanakan secara online. Fitur seperti WhatsApp, Zoom, dan BigBluBotton dapat digunakan untuk melaksanakan pembelajaran pada masa pandemi covid 19 saat ini. Belajar matematika dengan menggunakan fitur- fitur tersebut akan membantu seseorang untuk mengikuti perkembangan Ilmu Pengethauan dan Teknolgi (IPTEK). Tujuan pembelajaran matematika dalam kurikulum 2013 pada dimensi pendagogik modern dalam pembelajaran, yaitu menggunakan pendekatan scientific (ilmiah) (Fuadi, dkk., 2016).

Geometri merupakan salah satu topik pembelajaran matematika. Hal yang perlu diperhatikan dalam pembelajaran geometri pada masa pandemi ini adalah komunikasi. Dengan adanya komunikasi yang baik antara guru dan murid, pembelajaran secara online dapat terlaksana dengan lancar. Kemampuan komunikasi merupakan salah satu hal penting yang perlu diperhatikan dalam pembelajaran matematika. Menurut Wijayanto, dkk., (2018) kemapuan komunikasi mempunyai peranan penting dalam pembelajaran matematika antara lain membantu siswa untuk mempertajam dalam berfikir, sebagai alat menilai progres pemahan, dan membangun pengetahuan matematika. Menurut Jenab, dkk., (2018) kemampuan komunikasi dapat membantu secara intensif agar siswa telibat aktif dalam pembelajaran dan dapat menghilangkan kesan bahwa matematika merupakan salah satu pelajaran yang asing dan menakutkan. Menurut Hikmawati, dkk., (2019) ada tiga aspek kemampuan komunikasi, yaitu witten text, drawing, dan mathematical expression. Siswa yang memiliki kemampuan komunikasi sedang dan rendah belum mampu untuk memenuhi aspek mmathematical expression (Hikmawati, dkk., 2019). Hal tersebut terjadi karena faktor kebiasaan siswa dalam menyelesaikan soal, pemahaman konsep, dan progres dalam suatu pembelajaran matematika yang dilaksankan.

Kepribadian merupakan sesuatu yang dimiliki oleh setiap manusia yang diperoleh dari kebiasaan manusia itu sendiri (Denissa et al., 2015). Terdapat 4 jenis tipe kepribadian, yaitu sanguinis, koleris, melankolis, dan phlegmatis. Dalam situasi pembelajaran secara online ini, kepribadian siswa merupakan salah satu faktor yang dapat mempengaruhi efektifitas pembelajaran. Tujuan dari penelitian ini adalah untuk mendeskripsikan kemampuan komunikasi geometris siswa kelas 8 di era pandemi covid 19 yang ditinjau dari tipe kepribadian florence liitauer.

\section{Metode Penelitian}

Jenis penelitian ini adalah jenis penelitian deskriptif dengan pendekatan kualitatif, jenis penelitian yang digunakan dalam mendeskripsikan secara sistematis, faktual, dan akurat mengenai fakta-fakta dan sifat-sifat populasi daerah tertentu (Hikmawati, dkk., dalam Suryana, 2019; Adams, 2004; Mills, 2000; Moleong, 2011). Dalam hal ini peneliti mendeskripsikan kemampuan komunikasi geometris siswa kelas 8 di era pandemi covid 19 yang ditinjau dari tipe kepribadian florence littauer. Subjek penelitian ini adalah siswa kelas 8 SMP Negeri 1 Cluring. Pengambilan subjek penelitian dilakukan dengan metode snowball sampling. Langkah- langkah penelitian ini adalah sebagai berikut.

Kegiatan pendahuluan, seperti menentukan judul dan merumuskan masalah. Menyiapkan angket tipe kepribadian florence littauer, menyusun soal tes kemampuan komunikasi geometris, dan 
membuat pedoman wawancara. Pemvalidasian lembar instrumen oleh dua Dosen Pendidikan Matematika, FKIP, Universitas Jember. Menentukan tempat dan jadwal pelaksanaan peneltiian.

Pengambilan data secara online dengan cara memberikan link google form angket tipe kepribadian, memberikan soal tes melalui aplikasi WhatsApp, dan wawancara melalui WhatsApp. Angket yang digunakan yaitu angket tipe kepribadian florence littauer untuk mengetahui tipe kepribadian pada masing-masing siswa. Soal tes dilakukan pada 2 siswa yang dipilih dari setiap kepribadian dengan skor angket tertinggi dan skor angket terendah. Wawancara dilakukan setelah semua siswa mengerjakan soal tes yang disediakan dan dipergunakan untuk memperkuat data yang laiinya. Menganalisis data dengan cara menyusun data yang telah didapatkan. Membuat kesimpulan, dilakukan penarikan kesimpulan dari hasil analisis data yang diperoleh pada saat melakukan penelitian.

\section{Hasil dan Pembahasan}

Penelitian ini dimulai dengan memberikan link google form angket tipe kepribadianflorence littauer kepada siswa kelas 8 SMP Negeri 1 Cluring. Siswa yang mengisi link google form angket tipe kepribadian berjumlah 21 siswa. Berikut tabel hasil tipe kepribadian dari masing masing siswa.

Tabel 1. Hasil Penggolongan Tipe Kepribadian

\begin{tabular}{|c|l|l|l|l|l|l|}
\hline No & \multicolumn{1}{|c|}{ Nama } & Tipe Kepribadian & \multicolumn{1}{|c|}{ S } & \multicolumn{1}{|c|}{ K } & \multicolumn{1}{|c|}{ M } & P \\
\hline 1 & Jeni Rizkia Amanda & Melankolis & 6 & 5 & 22 & 7 \\
\hline 2 & Tirto Aji Pamungkas & Melankolis & 11 & 6 & 13 & 10 \\
\hline 3 & Mohamad Munirul Ichwan & Koleris & 7 & 13 & 11 & 9 \\
\hline 4 & Vitaliano Manuel Adiwinata & Sanguinis & 13 & 8 & 8 & 12 \\
\hline 5 & Tegar Fahreza & Sanguinis & 17 & 6 & 6 & 11 \\
\hline 6 & Indira Pratama Putri & Phlegmatis & 6 & 5 & 11 & 18 \\
\hline 7 & Elok Dwi Nur Safitri & Sanguinis & 13 & 8 & 10 & 9 \\
\hline 8 & Yulia Indah Kartika Sari & Sanguinis & 12 & 6 & 11 & 11 \\
\hline 9 & Para Dita Amelia Azhar & Sanguinis & 13 & 8 & 9 & 10 \\
\hline 10 & Jeny Meliana Putri & Sanguinis & 12 & 9 & 9 & 10 \\
\hline 11 & Resty Reynida & Koleris & 10 & 12 & 11 & 7 \\
\hline 12 & Muhammad Farhan Syarif H & Sanguinis & 14 & 6 & 9 & 11 \\
\hline 13 & Alfia Ustojik & Phlegmatis & 11 & 3 & 8 & 18 \\
\hline 14 & Neysha Cecillia Zahra & Phlegmatis & 9 & 8 & 10 & 13 \\
\hline 15 & Fahry Ibrahim A.K & Phlegmatis & 8 & 7 & 9 & 16 \\
\hline 16 & Alvira Indah Pratiwi & Phlegmatis & 11 & 2 & 8 & 19 \\
\hline 17 & Nimas Nurcahyani & Sanguinis & 14 & 11 & 5 & 10 \\
\hline 18 & Elvin Afdila & Koleris & 9 & 13 & 8 & 10 \\
\hline 19 & Chealse Rahmawati & Phlegmatis & 8 & 4 & 13 & 15 \\
\hline 20 & Rasya Panji Kurniawan & Phlegmatis & 9 & 10 & 7 & 14 \\
\hline 21 & M. Arya Zakiya & Sanguinis & 11 & 10 & 10 & 9 \\
\hline
\end{tabular}

Dari hasil Tabel 1 di atas, dipilih 1 siswa dengan skor angket tertinggi dan 1 siswadengan skor angket terendah pada setiap tipe kepribadian, sehingga jumlah subjek yang akan diberikan soal tes ada 8 siswa. Rinciannya adalah 2 siswa dengan tipe kepribadian sanguinis, 2 siswa dengan tipe kepribadian koleris, 2 siswa dengan tipe kepribadian melakolis, dan 2 siswa dengan 
tipe kepribadian phlegmatis. Soal tes diberikan berdasarkan indikator yang terdapat pada aspek written text, drawing, dan mathematicalexpression. Berikut adalah hasil analisis jawaban subjek dari soal tes yang telah diberikan.

Tabel 2. Hasil Analisis Profil Kemampuan Komunikasi Geometris Siswa Ditinjau dari Tipe

\begin{tabular}{|c|c|c|c|c|c|c|c|c|c|}
\hline \multirow{2}{*}{ No. Soal } & Aspek & \multicolumn{2}{|c|}{ Sanguinis } & \multicolumn{2}{|c|}{ Koleris } & \multicolumn{2}{|c|}{ Melankolis } & \multicolumn{2}{|c|}{ Phlegmatis } \\
\cline { 3 - 12 } & & S1 & S2 & K1 & K2 & M1 & M2 & P1 & P2 \\
\hline 1 & Written text & $\sqrt{ }$ & $\sqrt{ }$ & $\sqrt{ }$ & $\mathrm{X}$ & $\mathrm{X}$ & $\sqrt{ }$ & $\sqrt{ }$ & $\sqrt{ }$ \\
\hline 2 & Written text & $\sqrt{ }$ & $\sqrt{ }$ & $\sqrt{ }$ & $\sqrt{ }$ & $\mathrm{X}$ & $\sqrt{ }$ & $\sqrt{ }$ & $\sqrt{ }$ \\
\hline 3 & Drawing, & $\mathrm{X}$ & $\mathrm{X}$ & $\mathrm{X}$ & $\sqrt{ }$ & $\mathrm{X}$ & $\mathrm{X}$ & $\sqrt{ }$ & $\mathrm{X}$ \\
\hline 4 & Written text, & $\sqrt{ }$ & $\sqrt{ }$ & $\sqrt{ }$ & $\sqrt{ }$ & $\mathrm{X}$ & $\sqrt{ }$ & $\sqrt{ }$ & $\mathrm{X}$ \\
\hline 5 & Drawing & $\mathrm{X}$ & $\mathrm{X}$ & $\mathrm{X}$ & $\sqrt{ }$ & $\mathrm{X}$ & $\mathrm{X}$ & $\sqrt{ }$ & $\mathrm{X}$ \\
\hline 6 & $\begin{array}{c}\text { Mathematical } \\
\text { expression }\end{array}$ & $\sqrt{ }$ & $\mathrm{X}$ & $\sqrt{ }$ & $\mathrm{X}$ & $\mathrm{X}$ & $\mathrm{X}$ & $\sqrt{ }$ & $\mathrm{X}$ \\
\hline
\end{tabular}

Subjek S1 menunjukkan bahwa mampu mengidentifikasi informasi yang diketahuidan apa yang ditanyakan dalam soal, menuliskan strategi penyelesaian menggunakan istilah matematika dengan bahasa sendiri, dan siswa dapat menyajikan simbol atau notasimatematika dengan benar dan dapat menarik kesimpulan dengan tepat. Namun S1 belum dapat untuk menyajikan penyelesaian matematika dengan menggunakan gambar yang dapat diketahui pada soal. Berikut adalah hasil jawaban S1 untuk soal nomor 3.

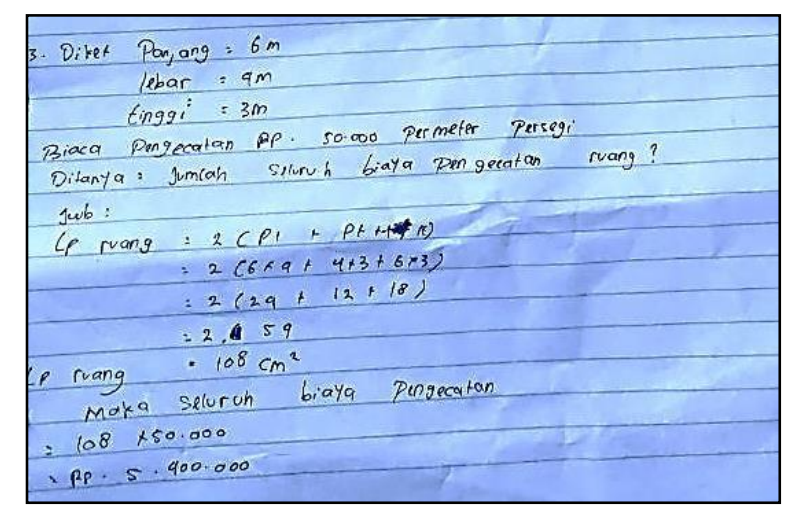

Gambar 1. Jawaban S1 Soal Nomor 3

Berdasarkan Gambar 1, Subjek S1 yaitu siswa yang bertipe sangunis dengan skor angket tertinggi memiliki kemampuan komunikasi geometris baik. Hal ini dikarenakan S1 dapat memenuhi 2 aspek dari 3 aspek yang ada dan memiliki jawaban yang benar pada setiap soal.

Subjek S2 mampu untuk mengidentifikasi yang diketahui dalam soal. Selain itu, S2 juga dapat meneyelesaikan soal dengan strategi penyelesaian menggunakan bahasanya senidri. Namun S2 belum 
dapat untuk menyajikan penyelesaian matematika dengan menggunakan gambar yang dapat diketahui pada soal. Berikut adalah hasil jawaban S2 untuk soal nomor 2

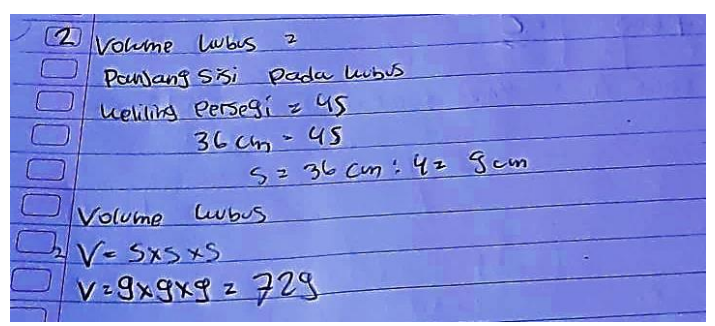

Gambar 2. Jawaban S2 Soal Nomor 2

Berdasarkan Gambar 4 dan Gambar 5, Subjek S2 yaitu siswa bertipe sanguinis dengan skor angket terendah memiliki kemampuan komunikasi geometris yang cukup baik. Hal ini dikarenakan S2 dapat menjawab 2 soal dengan benar dari 3 soal yang ada dan hanya mampu memenuhi aspek written text saja.

Subjek K1 mampu mengidentifikasi informasi dan hal apa yang ditanyakan dalam soal. Selain itu, K1 dapat menuliskan strategi penyelesaian menggunakan bahasa matematikanya sendiri dan dapat menyimpulkan jawaban dengan tepat dan benar. Namun, K1 belum dapat menyajikan penyelesaian matematika dengan menggunakan gambar yang dapat diketahui dari soal nomor 3 .

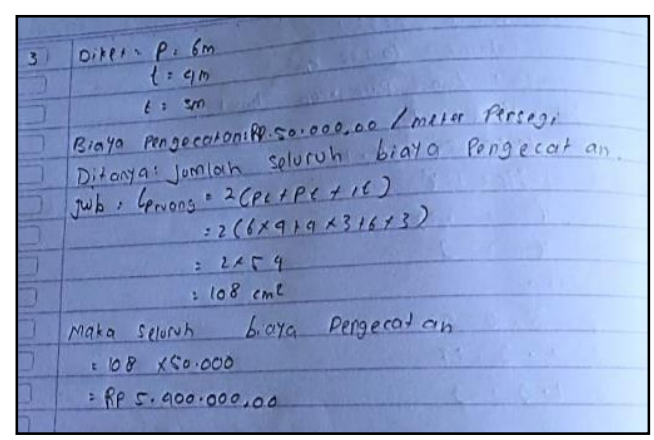

Gambar 3. Jawaban K1 Soal Nomor 3

Berdasarkan Gambar 8, Gambar 9, dan Gambar 10, Subjek K1 yaitu siswa bertipe koleris dengan skor angket tertinggi memiliki kemampuan komunikasi geometris yang baik. Hal ini ditunjukkan K1 dapat memenuhi aspek written text dan drawing, serta dapat menjawab 3 soal dengan benar dari 3 soal yang ada.

Subjek K2 menunjukkan bahwa K2 mampu mengidentifikasi informasi yang diketahui dalam soal, mengidentifikasi hal yang ditanyakan dalam soal, menuliskan strategi penyelesaian dengan bahasa sendiri, dan dapat menjelaskan penyelesaian menggunakan istilah matematika, serta siswa dapat menyajikan penyelesaian matematika dalam bentuk gambar dengan tepat dan jelas. Berikut adalah jawaban K2 untuk soal nomor 2 


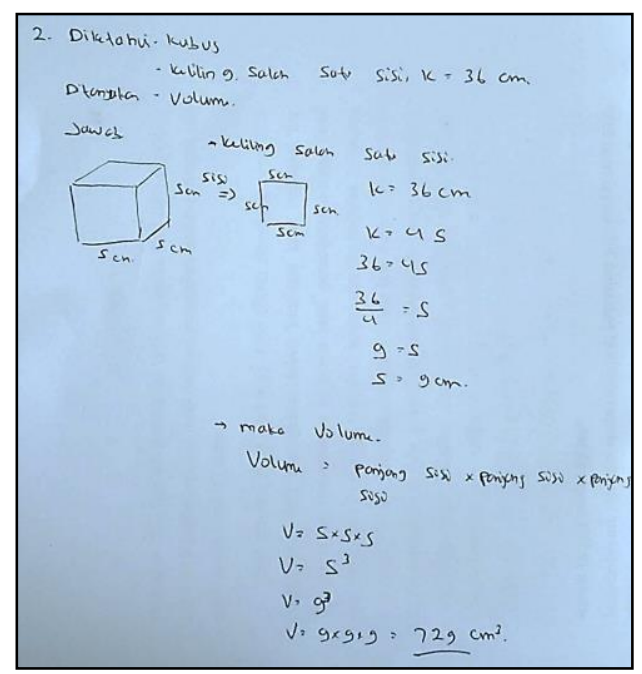

Gambar 4. Jawaban K2 Soal Nomor 2

Berdasarkan Gambar 11 dan Gambar 12, Subjek K2 yaitu siswa yang bertipe koleris dengan skor angket terendah memiliki kemampuan komunikasi geometris yang kurang baik. Hal ini ditunjukan K2 hanya dapat menjawab 1 soal dengan benar dari 3 soal yang ada dan dapat memenuhi aspek written text dan drawing. Berikut adalah hasil jawaban dari K2.

Subjek M1 belum mampu menuliskan informasi yang diketahui dan apa yang ditanyakan dalam soal. Selain itu, M1 mampu dalam menuliskan strategi penyelesaian matematika. M1 juga dapat menyajikan simbol ataupun notasi matematika dengan benar.Namun, M1 belum dapat menyajikan penyelesaian dengan gambar dan solusi yang tepatuntuk permasalahan pada soal nomor 3 tersebut. Berikut adalah hasil jawaban M1 untuksoal nomor 3

\begin{tabular}{|c|c|c|}
\hline 3. & $\mathcal{L}$ was dinding $=(2 p+2 l) t$ & Blaya : $60 \times 50.000$ \\
\hline D & $=(2.6+24) 3$ & $=3.000 .000$ \\
\hline$\square$ & $=(12+8) 3$ & $=R_{p} 3.000 .000$ \\
\hline$\square$ & $=20.3$ & $=$ \\
\hline$\square$ & $=60 \mathrm{~m}^{2}$ & \\
\hline$\square$ & & \\
\hline
\end{tabular}

Gambar 5. Jawaban M1 Soal Nomor 3

Berdasarkan Gambar 5, Subjek M1 yaitu siswa yang bertipe melankolis dengan skor angket tertinggi mimiliki kemampuan komunikasi geometris yang buruk. Hal ini ditunjukan M1 tidak dapat memenuhi semua aspek yang ada dan menjawab salah pada semua nomor soal tes yang telah diberikan.

Subjek M2 mampu mengidentifikasi informasi yang diketahui dan hal apa yang ditanyakan di dalam soal. M2 juga dapat menuliskan penyelesaian dengan notasi atau simbol matematika dengan tepat. Namun, M2 belum dapat menyelesaikan permasalahanpada soal nomor 3 dengan hasil yang 
tepat. Selain itu, M2 belum dapat menyajikan penyelesaian permasalahan dengan menngunkanan gambar yang sudah diketahui dalam soal. Berikut adalah jawaban M2 untuk soal nomor 3

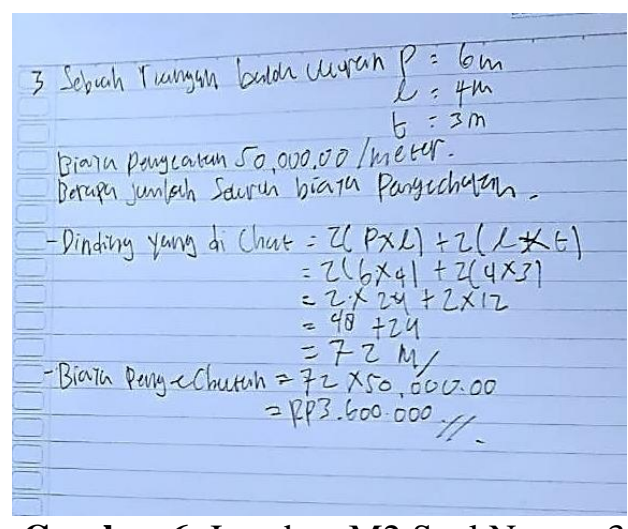

Gambar 6. Jawaban M2 Soal Nomor 3

Berdasarkan Gambar 6 di atas, Subjek M2 yaitu siswa yang bertipe melankolis dengan skor angket terendah mimiliki kemampuan komunikasi geometris yang cukup baik. Hal ini ditunjukan M2 hanya dapat memenuhi aspek written text pada soal nomor 1, 2 dan 3. Selain itu, Subjek M2 juga dapat menjawab 2 soal dengan benar.

P1 mampu mengidentifikasi informasi yang diketahui dan apa yang ditanyakan dalam soal nomor 3 tersebut. P1 juga mampu menuliskan strategi penyelesaian matematika dengan notasi ataupun simbol matematika dengan baik. Gambar di bawah juga menjelaskan bahwa P1 mampu menyajikan penyelesaian matematika dengan menggunakan gambar yang dapat diketahui dalam soal. Selain itu, P1 memberikan kesimpulan hasil yang tepat untuk solusi jawaban nomor 3 tersebut. Berikut adalah hasiljawaban dari P1 untuk soal nomor 3

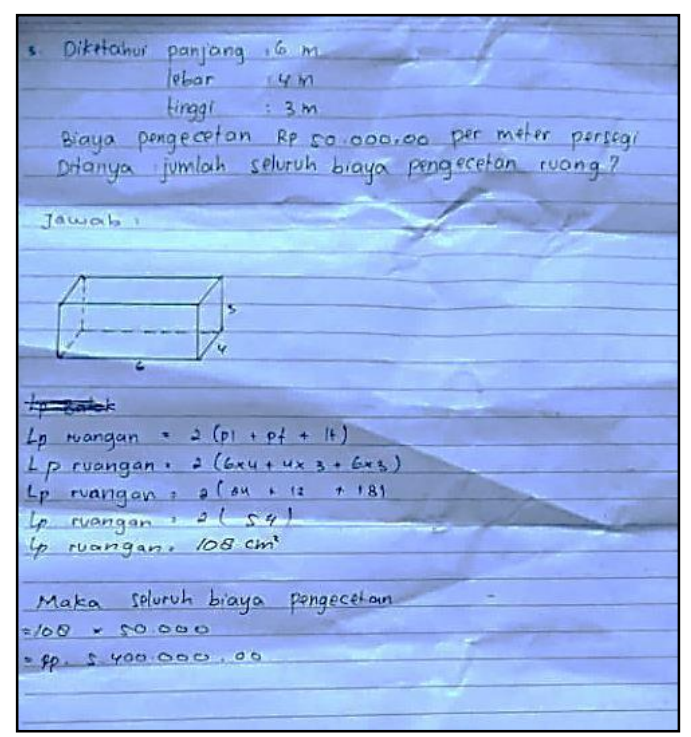

Gambar 7. Jawaban P1 Soal nomor 3 
Berdasarkan Gambar 7, Subjek P1 yaitu siswa yang bertipe phlegmatis dengan skor tertinggi memiliki kemampuan komunikasi geometris yang sangat baik. Hal ini ditunjukkan P1 dapat memenuhi semua aspek yang ada dan dapat menjawab soal tes dengan benar.

P2 mampu mengidentifikasi informasi yang dapat diketahui dan hal apa yang akan ditanyakan dalam soal. P2 juga mampu menuliskan strategi penyelesaian matematika dalam permaslahan soal nomor 1 dengan benar, sehingga subjek P2 mendapatkan hasil yang tepat dan benar. Berikut adalah hasil jawaban P2 untuk soal nomor 1.

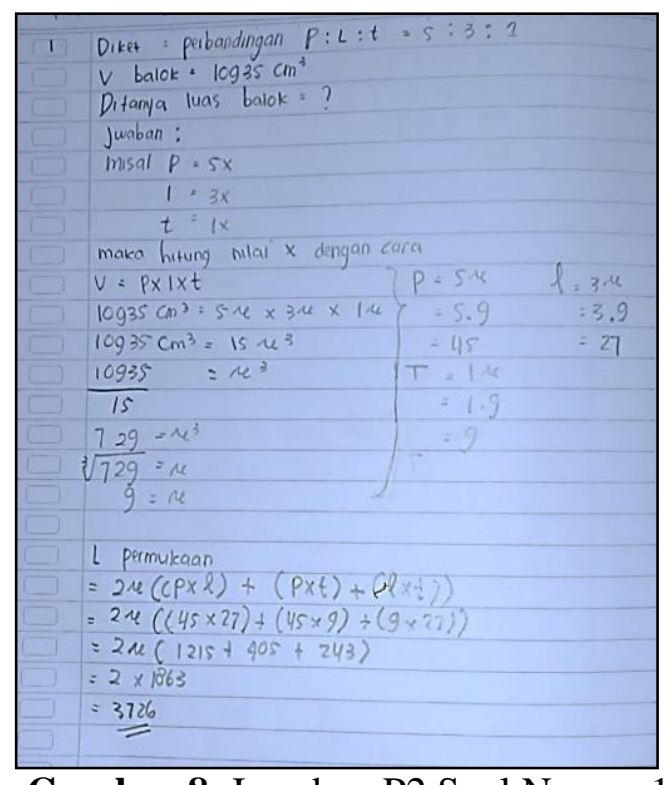

Gambar 8. Jawaban P2 Soal Nomor 1

Berdasrkan Gambar 8, Subjek P2 yaitu siswa yang bertipe phlegmatis dengan skor terendah memiliki kemampuan komunikasi geometris yang cukup buruk. Hal ini ditunjukkan P2 hanya memenuhi aspek written text yang ada di soal nomor 1 dan 2. Subjek P2 juga menawab 1 soal benar dari 3 soal tes yang sudah diberikan.

Di era pandemi covid 19 siswa yang memiliki kemampuan komunikasi geometris yang sangat baik yaitu subjek P1 yaitu siswa bertipe phlegmatis. Subjek P1 mampu memenuhi tiga aspek yang ada yaitu written text, drawing, dan mathematical expression dan dapat menyelesaikan soal tes yang sudah diberikan dengan benar dan tepat. Hal ini selaras dengan penelitian yang dilakukan Hikmawati, dkk., (2019), bahwa kemampuan komunikasi matematis siswa dengan kemampuan tinggi dapat dikatakan sangat baik dari kemampuannya dalam mengkomunikasikan ide-ide matematis dengan baik ke dalam tiga aspek komunikasi matematis yaitu aspek menulis (written text), aspek menggambar (drawing), dan aspek ekspresi matematika (mathematical expression). Pada Penelitian ini, subjek M1 yaitu siswa yang memiliki kemampuan melankolis mempunyai kemampuan 
komunikasi geometris yang buruk. Hal tersebut berbeda dengan hasil penelitian Hikmawati, dkk., (2019) yang menunjukkan bahwa siswa yang yang memiliki kemampuan rendah dapat memenuhi dua aspek yaitu aspek written text dan drawing. Hal ini ada faktor dari kepribadian yang muncul dari tingkah laku subjek M1 pada masa pandemi covid 19 saat ini. Subjek M1 tersebut mempunyai sifat yang cenderung pasrah dan apa adanya.

Di era pandemi covid 19, untuk subjek S1 dan S2 masing-masing memiliki kemampuan komunikasi yang baik dan cukup baik. Sifat kedua subjek tersebut memilikienergi dan antusiame yang tinggi. Untuk subjek K1 dan K2 pada era pandemi covid 19 masing-masing memiliki kemampuan komunikasi geometris yang baik dan kurang baik.Pada masa pandemi covid 19, subjek $\mathrm{K} 1$ cenderung mencari pemecahan masalah yang praktis dan subjek $\mathrm{K} 2$ cenderung menekankan pada hasil. Untuk Subjek M2, dimasa pandemi memiliki kemampuan komunikasi geometris yang cukup baik dan cenderung bersifat gigih. Untuk Subjek P2 pada masa pandemi memiliki kemampuan komunikasi geometris yang cukup buruk. Subjek tersebut memiliki sifat yang tidak berpendirian (Kasinah, 2013; Kuswarno, 2008; Ramdani, 2012).

\section{Kesimpulan}

Siswa tipe sanguinis pertama mampu memenuhi aspek written text dan mathematical expression dengan kemampuan komunikasi yang baik, sedangkan siswa yang kedua hanya mampu memenuhi aspek written text saja dengan kemampuan komunikasi yang cukup baik. Siswa sanguinis memiliki energi dan antusiame yang sangattinggi, hal ini juga terlihat saat sesi wawancara. Siswa yang bertipe koleris pertama mampu memenuhi aspek written text dan mathematical expression dengan kemampuan komunikasi geometris yang baik dan siswa yang kedua mampu memenuhi aspek written text dan drawing dengan kemampuan komunikasi yang kurang baik. Siswa koleris yang pertama cenderung mencari pemecahan yang praktis, sedangkan siswa koleris yang kedua cenderung menekankan pada hasil. Siswa yang bertipe melankolis yang pertama mempunyai kemampuan komunikasi geometris yang buruk, karena tidak mampu memenuhi indikator yang ada. Siswa yang kedua hanya mampu memenuhi indikator written text. Siswa melankolis yang pertama cenderung pasrah dan apa adanya. Untuk siswa melankolis yang kedua cenderung bersifat gigih. Siswa yang bertipe phlegmatis yang pertama mampu memenuhi semua indikator dari semua soal sehingga mempunyai kemampuan komunikasi geometris yang sangat baik dan siswa yang kedua hanya mampu memenuhi indikator written text sehingga mempunyai kemampuan komunikasigeometris yang cukup buruk. Selain itu, siswa phlegmatis pertama cenderung tenang dalam mengkomunikasikan solusi permasalahan, sedangkan siswa yang kedua cenderungtidak berpendirian.

\section{Daftar Pustaka}

Adams, J. (2004). The Imagination and Social Life. Qualitative Sociology, 27(3), 227-297.

Denissa, L., Widodo, P., Adisasmito, N. D., \& Piliang, Y. A. (2015). Public Engagement and the Making of Carnaval's Place at Jember Fashion Carnaval. Procedia - Social and Behavioral 
Sciences. https://doi.org/10.1016/j.sbspro.2015.05.061

Fuadi, R., Johar, R., dan Munzir, S. 2016. Peningkatkan Kemampuan Pemahaman dan Penalaran Matematis melalui Pendekatan Kontekstual. Jurnal Didaktika Matematika. 3(1): 47-54.

Hikmawati, N. N., Nurcahyono, N. A., Balkist, S. P. 2019. Kemampuan Komunikasi Matematis Siswa Dalam Menyelesaikan Soal Geometri Kubus dan Balok. PRISMA.VIII(1): 68-79.

Jenab, S., Ismlamiyati, M., dan Sariningsih, R. 2018. Meningkatkan kemampuan komunikasi matematis siswa smp untuk mengetahui pengaruh pendekatan kontekstual. Jurnal Pembelajaran matematika inovatif. 1(5): 941-948.

Kasinah, S. (2013). Classroom Action Research. Pionir. https://doi.org/10.17977/um099v1i12017p36

Kuswarno, E. (2008). Metode Penelitian Komunikasi : Etnografi Komunikasi. Widya Padjajaran.

Mills, G. E. (2000). Action research: A guide for the teacher researcher. Prentice- Hall, Inc.

Moleong, L. J. (2011). Metodologi penelitian kualitatif. PT Remaja Rosdakarya.

Ramdani, Y. (2012). Pengembangan instrumen dan bahan ajar untuk meningkatkan kemampuan komunikasi, penalaran, dan koneksi matematis dalam konsep integral. Jurnal Penelitian Pendidikan, 13(1), 44-52. http://jurnal.upi.edu/file/6-yani_ramdhana-edi.pdf

Wijayanto, A. D., Fajriah, S. N., dan Anita, I. W. 2018. Analisis Kemampuan KomunikasiMatematis Siswa SMP Pada Materi Segitiga dan Segiempat. Journal Cendekia: Jurnal Pendidikan Matematika. 2(1):97-104. 